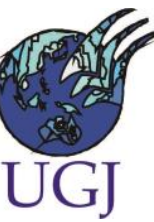

\title{
Peningkatan Hasil Belajar Geografi Siswa Menggunakan Model Pembelajaran Kooperatif Tipe Picture And Picture
}

\author{
Fenny Endrayani ${ }^{1 *}$, La Ode Amaluddin ${ }^{2}$, La Ode Nursalam ${ }^{3}$, \\ Rahma Musyawarah ${ }^{4}$, Syukri Nyompa ${ }^{5}$ \\ 1234 Jurusan Pendidikan Geografi Universitas Halu Oleo \\ ${ }^{5}$ Jurusan Geografi Universitas Negeri Makassar \\ Email : fennyendrayani05@gmail.com
}

(Received: Agustus 2019; Reviewed: Agustus 2019; Accepted: September 2019; Published: September 2019) penulis (https://creativecommons.org/licenses/by-nc/4.0/ ).

\begin{abstract}
SMAN 2 BauBau is one of the schools in BauBau City that is the object of research because the learning outcomes are still low, this is because only $62.5 \%$ of the tests that meet the KKM. The objectives of this study are: (1) To increase student learning activities in class XI IPS2 of SMAN 2 BauBau which are taught through the application of cooperative learning models of Picture and Picture types on flora and fauna material in Indonesia and the world. (2) To increase the teaching activities of teachers in class XI IPS2 SMAN 2 BauBau taught through the application of cooperative learning models Picture and Picture types on flora and fauna in Indonesia and the world Picture and Picture type on flora and fauna material in Indonesia and the world. Data about student learning activities and teacher teaching activities were obtained through observation sheets, while student geography learning outcomes data were obtained through learning outcomes tests, (cycles). The results showed: (1) Student activities with the application of the Contextual Approach learning model in cycle I amounted to 2.4 which included in the sufficient category, increased in cycle II to 3.7 which included in the category of good; (2) The teaching activities of the first cycle teachers mean the average score of the activities of the teachers is 2.8 which is included in the sufficient category and increased in the second cycle to 3.6 which is categorized as good; (3) There is an increase in the learning outcomes of class XI IPS-2 SMAN 2 BauBau after applying the Cooperative Learning model of the Picture and picture type. Where in the first cycle that is obtained $62.5 \%$ student mastery learning and in cycle II student learning completeness increased to $87.5 \%$.
\end{abstract}

Keywords: Cooperative learning type Picture and Picture; Geography; Learning Outcomes, SMAN 2 BauBau

\section{ABSTRAK}

SMAN 2 BauBau adalah salah satu sekolah di Kota BauBau yang menjadi objek peneliti karena hasil belajarnya masih rendah, hal ini dikarenakan hanya 62,5\% hasil ulangan yang memenuhi KKM. Tujuan penelitian ini adalah: (1) Untuk meningkatkan aktivitas belajar siswa di kelas XI IPS2 SMAN 2 BauBau yang diajar melalui penerapan model pembelajaran kooperatif tipe Picture and Picture 
pada materi flora dan fauna di indonesia dan dunia.(2)Untuk meningkatkan aktivitas mengajar guru di kelas XI IPS2 SMAN 2 BauBau yang diajar melalui penerapan model pembelajaran kooperatif tipe Picture and Picture pada materi flora dan fauna di indonesia dan dunia.(3)Untuk mengetahui peningkatan hasil belajar siswa di kelas XI IPS2 SMAN 2 BauBau yang diajar melalui penerapan model pembelajaran kooperatif tipe Picture and Picture pada materi flora dan fauna di indonesia dan dunia. Data tentang aktivitas belajar siswa dan aktivitas mengajar guru diperoleh melalui lembaran observasi, sedangkan data hasil belajar geografi siswa diperoleh melalui tes hasil belajar, (siklus). Hasil penelitian menunjukan: (1) Aktivitas siswa dengan penerapan model pembelajaran Pendekatan Kontekstual pada siklus I sebesar 2,4 yang termasuk pada kategori cukup, meningkat pada siklus II menjadi 3,7 yang termasuk pada katergori baik; (2) Aktivitas mengajar guru siklus I skor rata-rata aktivitas guru adalah 2,8 yang termasuk kategori cukup dan meningkat pada siklus II menjadi 3,6 yang berkategori baik; (3) Ada peningkatan hasil belajar geografi kelas XI IPS-2 SMAN 2 BauBau setelah menerapkan model Pembelajaran Kooperatif tipe Picture and picture. Dimana pada siklus I yaitu diperoleh ketuntasan belajar siswa 62,5\% dan pada siklus II ketuntasan belajar siswa meningkat menjadi 87,5\%.

Kata Kunci: Pembelajaran kooperatif tipe Picture and Picture; Geograf; Hasil Belajar, SMAN 2 BauBau.

\section{PENDAHULUAN}

Berdasarkan hasil observasi pada proses pembelajaran kelas XI IPS2 SMA Negeri 2 BauBau, diketahui sebagian besar siswa kelas XI IPS2 SMA Negeri 2 BauBau memiliki motivasi yang rendah terhadap mata pelajaran geografi. Hal ini diketahui dari aktifitas siswa selama proses pembelajaran berlangsung dan hasil belajar siswa yang belum memenuhi kriteria kentuntasan minimal. Pada aktivitas siswa selama proses pembelajaran berlangsung, siswa hanya mendengarkan apa yang disampaikan oleh guru saja.

Selain itu, siswa juga melakukan ativitas sendiri dan tidak menghiraukan penjelasan dari guru seperti mengobrol dengan teman sebangku hingga mengganggu teman yang lain. Berdasarkan nilai ulangan harian sebelumnya pada materi flora dan fauna di indonesia dan dunia ini didapatkan nilai rata-rata 65,5 dengan nilai terendah 60 dan tertinggi 85 .

Berdasarkan nilai ulangan harian geografi yang dilakukan pada materi flora dna fauna di Indonesia dan dunia terdapat $37,5 \%$ siswa yang memperoleh nilai di atas KKM yang telah ditentukan. Kriteria Ketuntasan Minimal (KKM) di SMA Negeri 2 BauBau adalah 75. Sementara $62,5 \%$ siswa memperoleh nilai di bawah KKM yang ditentukan. Secara nasional pembelajaran dianggap tuntas apabila ketercapaian KKM minimal 75\%. Dari data tersebut terlihat bahwa hasil belajar siswa masih perlu ditingkatkan. Kecenderungan model yag sering digunakan guru dalam mengajar adalah ceramah dan hafalan sehingga membuat siswa menjadi bosan dan kurang termotivasi dalam belajar.

Melihat kondisi hasil pembelajaran tersebut, maka untuk mengatasi masalah rendahnya motivasi dan hasil belajar siswa, peneliti ingin melakukan Penelitian Tindakan Kelas (PTK) pada mata pelajaran geografi dengan menggunakan model pembelajaran kooperatif tipe Picture and Picture.

Pembelajaran kooperatif merupakan suatu model pembelajaran yang sistematis dengan pengelompokkan siswa untuk 
tujuan menciptakan pendekatan pembelajaran secara afektif yang mengintegrasikan keterampilan sosial memuat akademis. Pembelajaran kooperatif, memposisikan siswa sebagai manusia yang memiliki pengetahua lewat pengalaman hidup siswa, dalam hal ini lingkungan memilki peran yang sangat besar dalam membentuk kepribadian dan motivasi siswa (Tukiran,dkk.,2011)

Picture and Picture merupakan teknik pembelajaran yang menggunaka media gambar yang dapat menarik perhatian siswa, serta dapat membangun motivasi siswa dalam belajar geografi khususnya ruang lingkup pengetahuan geografi. Model ini merupakan salah satu cara untuk mencapai tujuan pendidikan yang akan dicapai sebab model ini menyenagkan. Dengan penerapa model Picture and Picture diharapkan mampu mempengaruhi tingkat konsentrasi, kecepatan menyerap materi, dan motivasi siswa (Slavin,2008).

Pemilihan model pembelajaran Picture and Picture ini pada materi Flora dan Fauna di Indonesia dan Dunia diharapkan siswa dapat lebih mengerti mengenai materi yang disampaikan oleh guru. Materi Flora dan Fauna di Indonesia dan Dunia pada SMA kelas XI merupakan materi yang hanya dapat diimajinasikan saja oleh para siswa sehingga terkadang materi terkesan sulit dan jarang dipahami oleh siswa, maka dari itu pemilihan model pembelajaran ini yang bersifat menarik siswa diharapan mampu menguasai materi lebih dalam dan dapat membuat pembelajaran yang lebih menyenangkan.

\section{METODE}

\section{Jenis Penelitian}

Penelitian ini adalah Penelitian Tindakan Kelas (PTK). Dalam penelitian tindakan kelas bahwa ada empat komponen yang dikenalkan dalam penelitian tindakan, yaitu (a) perencanaan (planning), (b) tindakan (action), (c) observasi (observing), (d) refleksi (reflecting) hubungan dari keempat komponen tersebut saling berhubungan. PTK ini dilakukan dengan menerapkan model pembelajaraan kooperatif tipe Picture and Picture sebagai alternatif tindakan untuk meningkatkan hasil belajar geograsi siswa kelas XI IPS ${ }^{2}$ SMAN 2 BauBau pada materi Flora dan Floran di Indonesia dan Dunia.

\section{Tempat dan Waktu Penelitian}

Penelitian ini dilaksanakan pada semester ganjil tahun ajaran 2019/2020 yang bertempat di kelas XI IPS ${ }^{2}$ SMAN 2 BauBau.

\section{Subyek Peneletian}

Subyek penelitian ini adalah siswa kelas XI IPS ${ }^{2}$ SMAN 2 BauBau yang terdaftar tahun pelajaran 2019/2020 yang berjumlah 32 orang terdiri dari 19 siswa laki-laki dan 13 siswa perempuan. Penetapan kelas XI IPS ${ }^{2}$ sebagai subyek peneilitian didasarkan pada observasi awal dimana ketuntasan belajar yang diperoleh belum mencapai kriteria ketuntasan minimal dari sekolah.

\section{Teknik Pengumpulan Data}

Teknik pengumpulan data dalam penelitian ini adalah: (a). Data mengenai aktivitas siswa diambil dengan mmenggunakan lembar observasi dnegan cara memberikan skor pada aspek aktivitas yang dilakukan untuk siswa sesuai dengan kriteria yang telah ditentukan. (b). Data mengenai hasil belajar Geografi dimabil dengan menggunakan tes hasil belajar (tes siklus) dengan bentuk tes berupa essay yang mencakup semua indikator pembelajaran pada siklus I serta siklus II.

\section{Teknik Analisi Data}

Teknik analisis data yang digunakan berupa analisis deskriptif yang dimaksudkan ntuk memberikan gambaran peningkatan hasil belajar geografi siswa yang diajarkan dengan menggunakan model pembelajaran Picture and Picture. Langkah-langkah analisis data sebagai berikut:

a) Menentukan hasil belajar siswa. Dalam menentukan nilai hasil belajar siswa rentang nilai yang digunakan untuk tes uraian dlam penelitian ini adlaah 0 sampai 100 dengan rumus: 


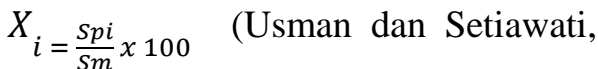
2001) Dengan:

$\mathrm{Xi}=$ Nilai yang diperoleh siswa ke-I

Spi = Skor yang diperoleh siswa ke-I

$\mathrm{Sm}=$ Skor maksimum yang mungkin dicapai (skor ideal)

b) Menghitung Standar Deviasi (SD) dengan menggunakan rumus

$S D=\sqrt{\frac{\sum_{\mathrm{i}=1}^{\mathrm{n}}(\mathrm{Xi}-\bar{X})}{n-1}} \quad($ Sudjana, 2002)

Dengan:

$\mathrm{SD}=$ Standar Deviasi

$\bar{X}=$ Nilai rata-rata yang diperoleh siswa

$\mathrm{Xi}=$ Nilai yang diperoleh tiap siswa

$\mathrm{n}=$ Banyaknya siswa

c) Menghitung nilai rata-rata hasi belajar siswa dengan rumus

$\bar{X}=\frac{\sum_{i=1}^{n} X i}{n}($ Sudjana, 2002)

Dengan:

$\bar{X}=$ Nilai rata-rata yang diperoleh siswa

$\mathrm{n}=$ Jumlah siswa secara keseluruhan

$\mathrm{Xi}=$ Nilai yang diperoleh tiap siswa

d) Menetukan tingkat pencapaian ketuntasan belajar

Presentase jumlah siswa yang hasil belajarnya sudah tuntas, dengan menggunakan rumus:

$$
\% \text { Tuntas }=\frac{\sum T B}{\mathrm{~N}} \times 100 \%
$$

Keterangan:

$\sum T B=$ Jumlah siswa yang tuntas belajar

$\mathrm{N}=$ Jumlah siswa secara keseluruhan Nilai Klasikal $=\frac{\text { Nilai rata-rata }}{\text { nilai ideal }} \times 100 \%$

(Sudjana, 2002)

\section{HASIL DAN PEMBAHASAN}

Hasil

Siklus I

\section{Data Aktivitas Siswa Siklus I}

Data aktivitas siswa kelas XI IPS ${ }^{2}$ SMA Negeri 2 BauBau selama proses pembelajaran dengan menerapkan Model pembelajaran Kooperatif tipe Picture and Picture pada materi Flora dan Fauna di Indonesia dan Dunia yang diperoleh menggunakan lembar observasi aktivitas siswa pada setiap pertemuan dengan cara memberikan skor pada setiap aspek aktivitas yang dilakukan oleh siswa sesuai dengan criteria yang telah ditentukan Untuk dapat melihat gambaran rata-rata aktivitas belajar siswa selama pembelajaran pada siklus I pertemuan I dan II dapat dilihat pada gambar 1 berikut:

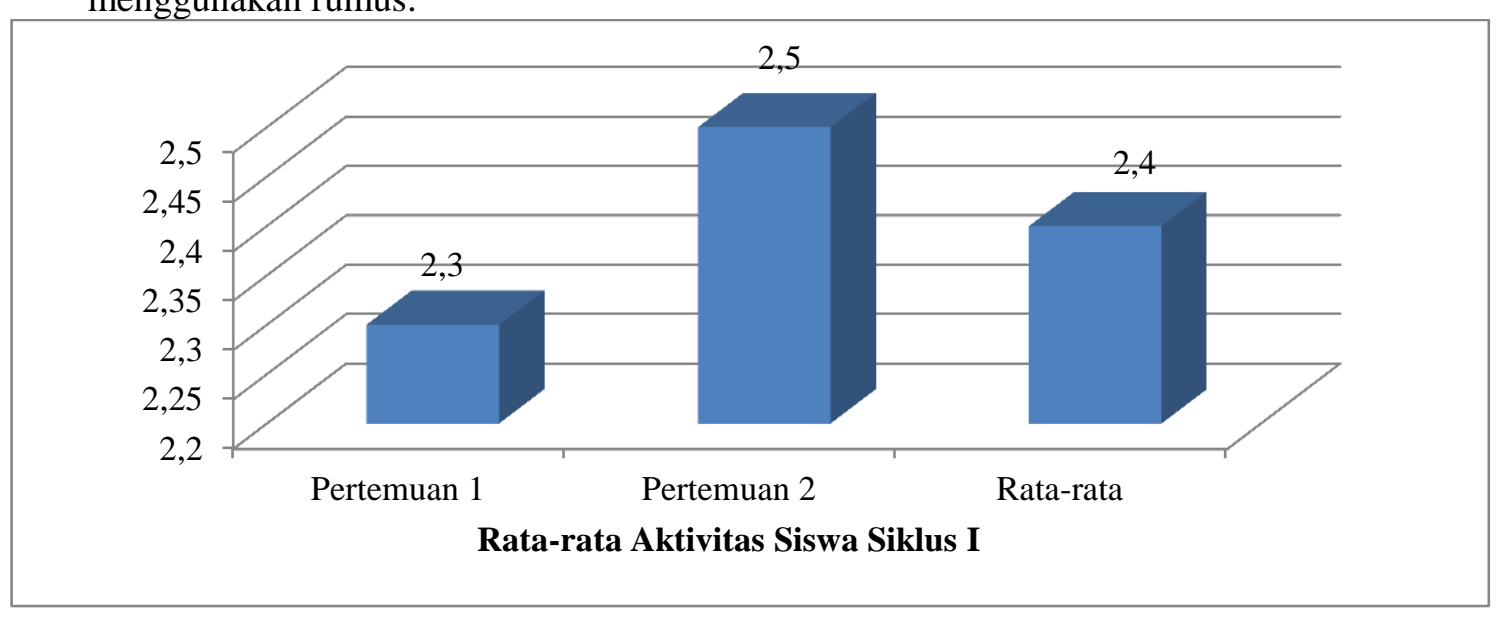

Grafik 1. Skor Rata-Rata Aktivitas Siswa Siklus I

\section{SIMPULAN DAN SARAN}

Berdasarkan grafik 1 di atas tentang hasil observasi aktivitas belajar siswa dapat diperoleh gambaran bahwa hasil aktivitas belajar siswa tersebut masih belum memenuhi criteria ketuntasan minimal yaitu 3,0, karena rata-rata aktivitas siswa masih mencapai ratarata 2,4 yang berkategorikan cukup. Pada siklus I, aktivitas belajar siswa yang 
mendapatkan skor terendah dengan nilai ratarata sebesar 2,2 adalah aktivitas belajar siswa no 5 yaitu peserta didik mengolah informasi yang sudah dikumpulkan dari hasil kegiatan mengumpulkan informasi. Sedangkan aktivitas siswa yang mendapatkan skor tertinggi dengan nilai rata-rata sebesar 3 adalah peserta didik menyimak secara seksama penjelasan guru setelah melihat potongan-potongan gambar.

\section{Data Aktivitas Mengajar Guru Siklus I}

Gambaran aktivitas guru dalam
mengelola pembelajaran menggunakan Model pembelajaran Kooperatif type Picture and Picture pada materi Floran dna Fauna di Indonesia dan Dunia diperoleh dengan menggunakan lembar observasi aktivitas mengajar guru pada siklus I.

Untuk mendapatkan gambaran rata-rata aktivitas mengajar guru selama pembelajaran pada siklus I pertemuan I dan II dapat dilihat pada gambar 2 berikut:

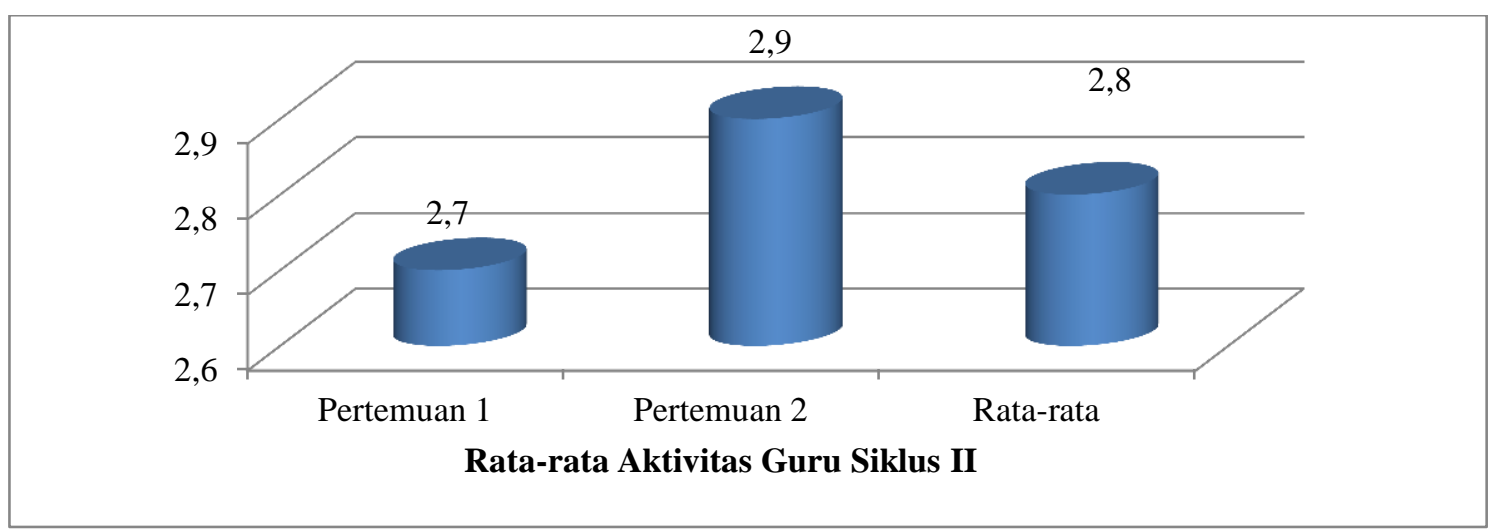

Grafik 2. Skor Rata-rata Aktivitas Guru Siklus I

Berdasarkan grafik 2 di atas tentang hasil observasi aktivitas mengajar guru dapat diperoleh gambaran bahwa hasil aktivtas mengajar guru tersebut masih belum memenuhi criteria ketuntasan minimal yaitu 3,0, karena rata-rata aktivtas mengajar guru masih mencapai rata-rata 2,8 yang berkategorikan cukup.

Pada siklus I, aktivitas mengajar guru yang mendapatkan skor terendah dengan nlai rata-rata sebesar 2 adalah aktivitas mengajar guru no 18 dan 19 pada kegiatan akhir yaitu Guru menyimpulkan hasil diskusi terkait jawaban pertanyaan-pertanyaan kelompok pada materi yang dipelajari, Guru mengevaluasi seluruh rangkaian aktivitas pembelajaran dan hasil-hasil yang diperoleh untuk selanjutnya secara bersama menemukan manfaat langsung maupun tidak langsung dari hasil pembelajaran yang telah berlangsung. Sedangkan aktivitas mengajar guru yang mendapat skor tertinggi dengan nilai rata-rata sebesar 4 adalah aktivitas mengajar guru pada no 3,5,6,8,9,15 pada kegiatan inti yaitu Guru mengecek kehadiran siswa, Guru menjelaskan tujuan pembelajaran yang akan dipelajari, Guru membagi siswa dalam 6 kelompok,masing-masing beranggotakan 5 siswa dan membagikan LKS, serta menjelaskan maksud dari penugasan yang terdapat pada LKS, Guru memberikan rangsangan kepada peserta didik, berupa stimulan pejelasan potongan-potongan gambar terkait materi yang akan dipelajari, Guru membagikan potongan-potongan gambar kepada peserta didik, Selama diskusi kelompok berlangsung, guru melakukan pengamatan untuk menilai sikap dan kinerja diskusi kelompok.

\section{Data Hasil Belajar Siswa}

Data hasil belajar geografi siswa kelas XI IPS 3 SMA Negeri 2 BauBau pada materi pokok Flora dan Fauna di Indonesia dan Dunia diperoleh dengan menggunakan lembar tes hasil belajar berupa soal pilihan ganda yang diberikan pada akhir siklus. Berdasarkan hasil analisis desktiptif terhadap hasil belajar siswa pada siklus I tersebut, diperolehdata seperti pada table 1 berikut: 
Tabel 1. Data Analisis Ketuntasan Hasil Belajar Siswa pada Siklus I

\begin{tabular}{|c|c|c|c|}
\hline Skor & Jumlah Siswa & Presentase & Ketuntasan Belajar \\
\hline $0-74$ & 12 & $37,5 \%$ & Belum Tuntas \\
\hline $75-100$ & 20 & $62,5 \%$ & Sudah Tuntas \\
\hline Jumlah & $\mathbf{3 2}$ & $\mathbf{1 0 0 \%}$ & \\
\hline Keterangan: & $: \mathbf{1 2}$ Orang \\
\hline Tidak Tuntas & $: \mathbf{2 0}$ Orang \\
\hline Tuntas & $: \mathbf{7 6}$ \\
\hline Nilai Rata-Rata & $: \mathbf{9 0}$ \\
\hline Nilai Maksimum & $\mathbf{5 0}$ \\
\hline Nilai Minimum & \\
\hline
\end{tabular}

Tabel 1 di atas menunjukan bahwa ketuntasan belajar siswa pada siklus I yang memperoleh nilai antara $0-74$ berjumlah 12 orang dengan persentase $37,5 \%$, sedangkan siswa yang telah memperoleh skor antara 75-100 berjumlah 20 orang dengan persentase $62,5 \%$, namun belum mencapai indicator ketuntasan keberhasilan yaitu $80 \%$.

Siklus II

4. Data Aktivitas Siswa Siklus II

Data aktivitas siswa kelas XI IPS2 SMA Negeri 2 BauBau selama proses pembelajaran dengan menerapkan Model pembelajaran
Kooperatif tipe Picture and Picture pada materi Flora dan Fauna di Indonesia dan Dunia yang diperoleh menggunakan lembar observasi aktivitas siswa pada setiap pertemuan dengan cara memberikan skor pada setiap aspek aktivitas yang dilakukan oleh siswa sesuai dengan criteria yang telah ditentukan.

Untuk mendapatkan gambaran rata-rata aktivitas siswa selama pembelajaan pada siklus II Pertemuan I dan II dapat dilihat pada grafik 3 berikut:

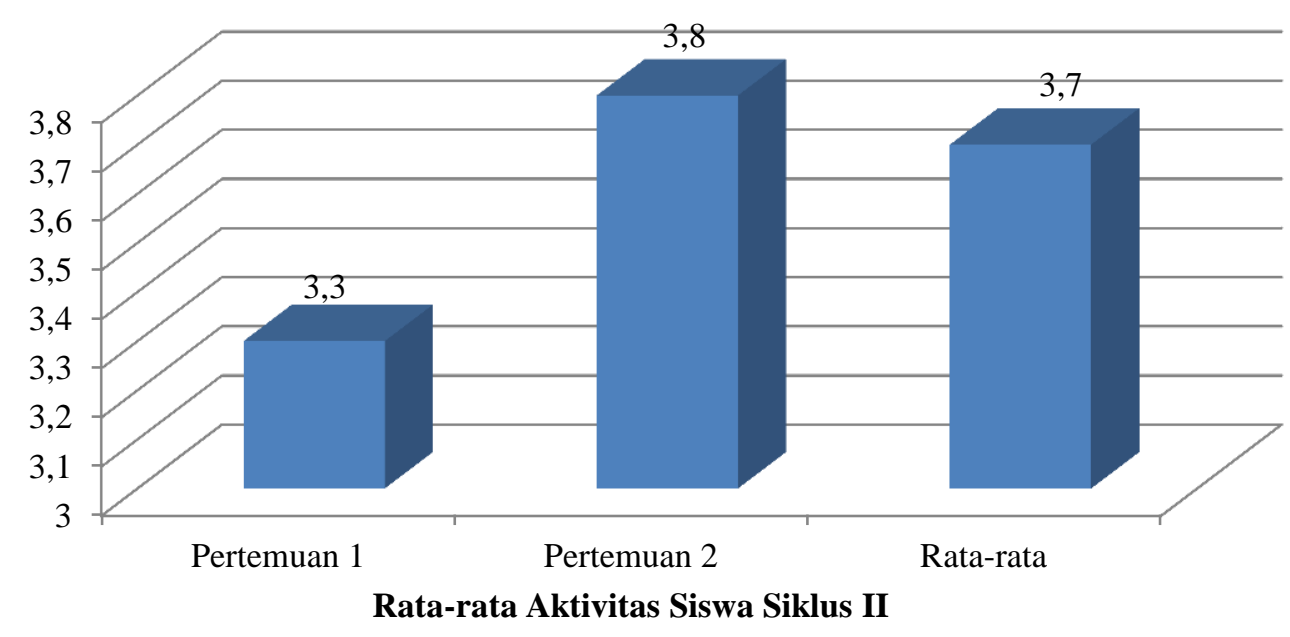

Fenny Endrayani, La Ode Amaluddin, La Ode Nursalam, Rahma Musyawarah, Syukri Nyompa Peningkatan Hasil Belajar Geografi Siswa Menggunakan Model Pembelajaran Kooperatif Tipe Picture And Picture 
Grafik. 3 Skor Rata-rata Aktivitas Siswa Siklus II

Berdasarkan grafik 3 di atas tentang hasil observasi aktivitas belajar siswa dapat diperoleh gambaran bahwa hasil aktivitas belajar siswa tersebut masih belum memenuhi criteria ketuntasan minimal yaitu 3,0, karena rata-rata aktivitas siswa masih mencapai ratarata 3,7 yang berkategorikan baik. Pada siklus II, aktivitas belajar siswa yang mendapatkan skor terendah dengan nilai rata-rata sebesar 3,2 adalah aktivitas belajar siswa no 5 yaitu peserta didik mengolah informasi yang sudah dikumpulkan dari hasil kegiatan mengumpulkan informasi. Sedangkan aktivitas siswa yang mendapatkan skor tertinggi dengan nilai rata-rata sebesar 3,8 adalah belajar siswa no 2 yaitu Peserta didik mencari jawaban pertanyaan yang terdapat di
LKS dengan memanfaatkan buku bahan ajar geografi kelas XI dan referensi lain.

\section{Data Aktivitas Guru Siklus II}

Gambaran aktivitas guru dalam
mengelola pembelajaran menggunakan Model pembelajaran Kooperatif type Picture and Picture pada materi Floran dna Fauna di Indonesia dan Dunia diperoleh dengan menggunakan lembar observasi aktivitas mengajar guru pada siklus II.

Untuk mendapatkan gambaran rata-rata aktivitas mengajar guru selama pembelajaran pada siklus II pertemuan I dan II dapat dilihat pada grafik 4 berikut:

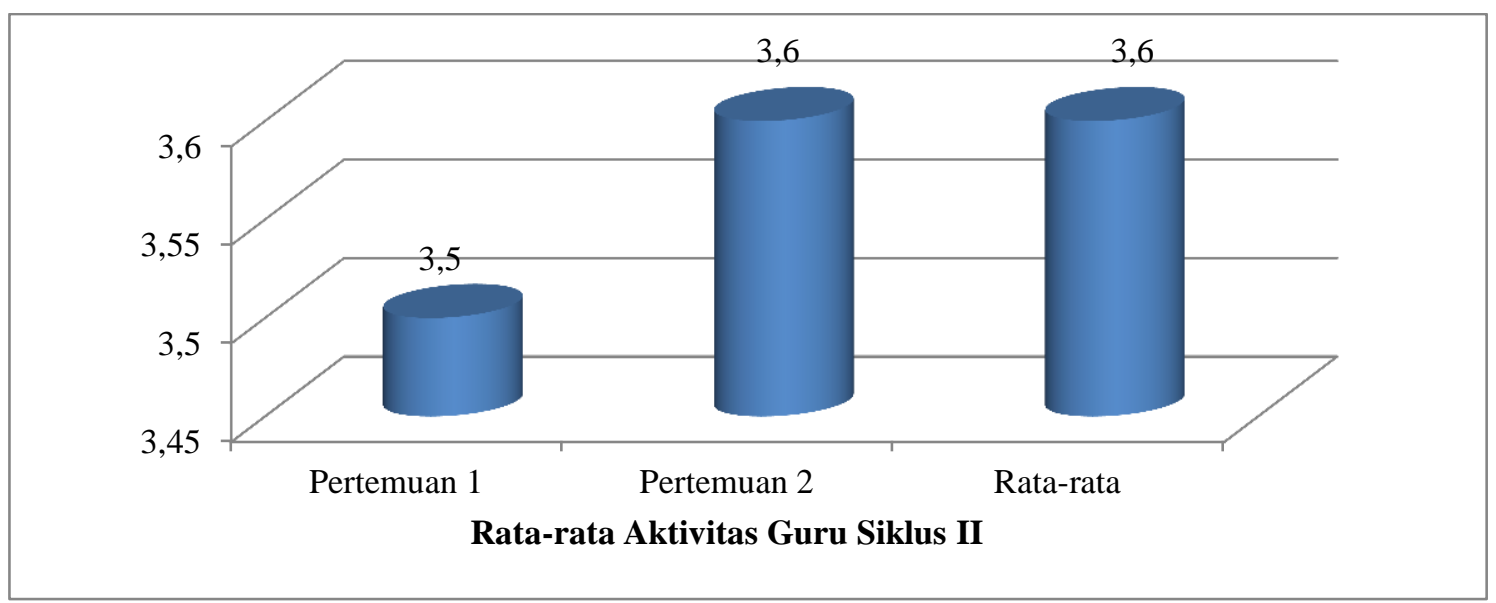

Grafik. 4 Skor Rata-rata Aktivitas Guru Siklus

Berdasarkan grafik $4 \mathrm{di}$ atas tentang hasil observasi aktivitas mengajar guru dapat diperoleh gambaran bahwa hasil aktivitas mengajar guru tersebut masih belum memenuhi criteria ketuntasan minimal yaitu 3,0, karena rata-rata aktivtas mengajar guru masih mencapai rata-rata 3,6 yang berkategorikan baik.

Pada siklus II, aktivitas mengajar guru yang mendapatkan skor terendah dengan nlai rata-rata sebesar 2,5 adalah aktivitas mengajar guru no 19 pada kegiatan akhir yaitu guru mengevaluasi seluruh rangkaian aktivitas pembelajaran dan hasil-hasil yang diperoleh untuk selanjutnya secara bersama menemukan manfaat langsung maupun tidak langsung dari hasil pembelajaran yang telah berlangsung. Sedangkan aktivitas mengajar guru yang mendapat skor tertinggi dengan nilai rata-rata sebesar 4 adalah aktivitas mengajar guru pada no $3,5,6,8,9,15,21,22,23$ yaitu Guru mengecek kehadiran siswa, Guru menjelaskan tujuan pembelajaran yang akan dipelajari, Guru membagi siswa dalam 6 kelompok,masingmasing beranggotakan 5 siswa dan membagikan LKS, serta menjelaskan maksud dari penugasan yang terdapat pada LKS, Guru memberikan rangsangan kepada peserta didik, berupa stimulan pejelasan potongan-potongan gambar terkait materi yang akan dipelajari, Guru membagikan potongan-potongan gambar kepada peserta didik, Selama diskusi kelompok berlangsung, guru melakukan pengamatan untuk menilai sikap dan kinerja diskusi kelompok, Guru meminta siswa mengumpulkan jawaban lembar kerja siswa 
dan hasil diskusi, Guru menginformasikan rencana kegiatan pembelajaran untuk pertemuan berikutnya, Menutup kegiatan pembelajaran dengan berdoa bersama sesuai dengan agama dan kepercayaannya masingmasing. Pada siklus II dari 23 aspek aktivitas mengajar guru yang diobservasikan telah memperoleh nilai rata-rata yang berkategorikan baik, karena secara keseluruhan rata-rata aktivitas mengajar guru meningkat dari siklus I ke siklus II.

\section{Data Hasil Belajar Siswa Siklus II}

Data hasil belajar geografi siswa kelas XI IPS 3 SMA Negeri 2 BauBau pada materi pokok Flora dan Fauna di Indonesia dan Dunia diperoleh dengan menggunakan lembar tes hasil belajar berupa soal pilihan ganda yang diberikan pada akhir siklus. Berdasarkan hasil analisis desktiptif terhadap hasil belajar siswa pada siklus I tersebut, diperoleh data seperti pada tabel 2 berikut:

Tabel 2. Data Analisis Ketuntasan Hasil Belajar Siswa pada Siklus II

\begin{tabular}{|c|c|c|c|c|}
\hline Skor & Jum & Siswa & Presentase & Ketuntasan Belajar \\
\hline $0-74$ & & & $12,5 \%$ & Belum Tuntas \\
\hline $75-100$ & & & $87,5 \%$ & Sudah Tuntas \\
\hline Jumlah & & & $100 \%$ & \\
\hline \multicolumn{5}{|c|}{ Keterangan: } \\
\hline \multicolumn{2}{|c|}{ Tidak Tuntas } & \multicolumn{2}{|c|}{ : 4 Orang } & \\
\hline \multicolumn{2}{|l|}{ Tuntas } & \multicolumn{2}{|c|}{ : 28 Orang } & \\
\hline \multicolumn{2}{|c|}{ Nilai Rata-Rata } & $: 81$ & & \\
\hline \multicolumn{2}{|c|}{ Nilai Maksimum } & $: 90$ & & \\
\hline \multicolumn{2}{|c|}{ Nilai Minimum } & : 70 & & \\
\hline \multicolumn{5}{|c|}{ Presentase Ketuntasan : $87,5 \%$} \\
\hline
\end{tabular}

Tabel 2 di atas menunjukan bahwa ketuntasan belajar siswa pada siklus II yang memperoleh nilai antara $0-74$ berjumlah 4 orang dengan persentase $12,5 \%$, sedangkan siswa yang telah memperoleh skor antara 75-100 berjumlah 28 orang dengan persentase $87,5 \%$. Hasil ini sudah jauh lebih baik jika dibandingkan dengan skor perolehan siswa pada siklus I. Dalam hal ini, indikator ketuntasan belajar siswa telah mencapai atau berhasil, dimana secara klasikal, yaitu jika nilai siswa yang telah mencapai KKM (75) adalah 87,5\%, maka dikatakan hasil penelitian telah mencapai dan berhasil.

\section{Pembahasan}

\section{Aktivitas Belajar Siswa Selama KBM Berlangsung}

Berdasarkan permasalahan pertama tentang bagaimana gambaran aktivitas belajar siswa dalam proses belajar mengajar pada materi pokok flora dan fauna di Indonesia dan dunia yang diajar dengan menerapkan model pembelajaran kooperatif type picture and picture, dapat dijelaskan berdasarkan hasil pengamatan pada setiap siklus baik siklus I maupun siklus II yang menunjukan peningkatan kearah yang lebih baik. Peningkatan ini salah satunya ditunjukan oleh adanya respon positive dari siswa terhadap model yang digunakan. Peningkatan aktivitas siswa tersebut menunjukan adanya minat dan 
antusias siswa dalam mengikuti proses pembelajaran pada materi flora dan fauna di Indonesia dan dunia yang diajar dengan menerapkan model pembelajaran kooperatif type picture and picture.

Pada siklus I berdasarkan hasil analisis deskriptif terhadap aktivitas siswa menunjukan skor rata-rata aktivitas siswa pada siklus I sebesar 2,8 yang berkategorkan cukup. Pada sisklus I ada beberapa aktivitas siswa yang masih tergolong kurang yaitu siswa belum optimal dalam menyimak hasil diskusi kelompok lain. Berdasarkan hasil refleksi pada siklus I ditemukan ada beberapa aktivitas siswa yang masih belum terlaksana dengan baik. Olehnya ini dilakukan perbaikan pada siklus berikutnya.

Pada siklus II dari hasil analisis deskriptif terhadap skor rata-rata aktivitas siswa pada siklus II menunjukan adanya peningkatan dari aktivitas siswa siklus I, dimana skor rata-rata aktivitas siswa pada siklus II sebesar 3,7 dengan kategori baik. Hal ini menunjukan bahwa penelitian telah berhasil karena tela memenuhi standar minimal aktivitas belajar siswa yaitu 3,0.

\section{Aktivitas Mengajar Guru Selama KBM Berlangsung}

Berdasarkan hasil pengamatan pada dua siklus baik itu siklus I maupun siklus II, untuk aktivitas mengajar guru dengan menggunakan model pembelajaran kooperatif type picture and picture menunjukan peningkatan kea rah yang lebih baik.

Pada siklus I berdasarkan analisis deskriptif aktivitas mengajar guru menunjukan skor rata-rata 2,8 yang berkategori cukup. Aktivitas mengajar guru pada siklus I yang masih rendah berdasarkan hasil refleksi yaitu guru kurang menyimpulkan hasil diskusi terkait jawaban pertanyaan-pertanyaan kelompok pada materi yang dipelajari.

Berdasarkan hasil refleksi terhadap aktivitas guru, dengan mengetahui kekurangan-kekurangan pada siklus I, maka diperlukan pembenahan pada proses pembelajaran siklus II agar mencapai hasil yang optimal dari siklus sebelumnya.

Sehingga pada siklus II aktivitas mengajar guru menunjukan peningkatan, dimana pada siklus II skor rata-rata aktivitas guru memperoleh nilai sebesar 3,6 yang berkategorikan baik. Hasil analisis dan pengamatan pada siklus II ini menunjukan adanya peningkatan aktivitas mengajar guru. Hal ini menunjukan bahwa penelitian ini telah berhasil karena telah memenuhi standar minimal aktivitas mengajar guru yaitu 3,0.

\section{Hasil Belajar Siswa}

Penggunaan model pembelajaran kooperati type picture and picture dapat meningkatkan hasil belajar Geografi siswa kelas XI IPS ${ }^{2}$ SMA Negeri 2 BauBau pada materi pokok flora dan fauna di Indonesia dan Dunia dapat dijelaskan bahwa berdasarkan hasil analisis deskriptif kuantitatif yang dilakukan terhadap hasil belajar siswa pada setiap siklus cenderung mengalami peningkatan kearah yang lebih baik.

Pada siklus I, dari hasil tes hasil belajar siswa pada siklus I diperoleh nilai minimum sebesar 50; nilai maksimum 90; rata-rata siswa sebesar 76 secara klasikal dari 32 siswa yang mencapai presentase ketuntasan hasil belajar yaitu 20 siswa atau $62,5 \%$ yang mencapai nilai $\geq 75$ sesuai dengan nilai KKM Geografi yang ditentukan oleh sekolah dan terdapat 12 orang siswa dengan presentase sebesar 37,5\% yang nilainya belum mencapai KKM yang ditentukan oleh skolah yaitu 75. Presentase ketuntasan belajar secara klasikal minimal $80 \%$.

Data tersebut terlihat bahwa dalam pembelajaran ini tampak bahwa siswa kurang membaca buku teks yang terkait dengan materi yang dipelajari dan juga siswa kurang aktif serta kurang kompak dalam mengerjakan LKS.

Setelah melakukan analisis dan refleksi hasil belajar siswa pada siklus I, Pguru atau peneliti mencoba melakukan perbaikan dalam proses belajar mengajar agar pada siklus selanjutnya siswa yang memenuhi ketuntasan belajar dapat meningkat lagi seperti yang diharapkan.Pada siklus II, dari hasil tes hasil belajar siswa pada siklus II diperoleh nilai minimum sebesar 70 ; nilai maksimum 90; rata-rata siswa sebesar 81 . Terdapat sebanyak 28 siswa yang memperoleh nilai $\geq 75$ atau ketuntasan hasil belajar secara klasikal sebesar $87,5 \%$ sedangkan jumlah siswa yang hasil belajarnya 
di bawah KKM yang memperoleh nilai $<75$ sebanyak 4 orang atau $12,5 \%$ yang belum tuntas. Dari hasil tersebut, menunjukan peningkatan hasil belajar dari siklus I ke siklus II, walaupun masih ada beberapa siswa yang belum mencapai ketuntasan belajar.

Pada siklus II target ketuntasan hasil belajar siswa telah tercapai yaitu $87,5 \%$ siswa telah tuntas dalam hasil belajarnya. Dalam penelitian ini keberhasilan siswa dalam tes hasil belajar siklus II memberikan gambaran bahwa penerapan model pembelajaran kooperatif type picture and picture mampu meningkatkan hasil belaja siswa.

Dengan ketercapaian tersebut, peneliti dapat menyimpulkan bahwa penerapan model pembelajaran kooperatif type picture and picture dapat meningkatkan hasil belajar geografi siswa kelas XI IPS ${ }^{2}$ SMA Negeri 2 BauBau khususnya pada materi pokok floran dan fauna di Indonesia dan dunia.

\section{KESIMPULAN DAN SARAN Kesimpulan}

Berdasarkan hasil dalam penelitian ini dapat di tarik kesimpulan sebagai berikut yaitu aktivitas belajar siswa dengan menggunakan model pembelajaran kooperatif type picture and picture pada setiap siklus meningkat. Hal ini ditunjukan dengan skor rata-rata pada setiap siklus, pada siklus I skor rata-rata aktivitas belajar siswa adalah 2,4 yang termasuk kategori cukup dan meningkat pada siklus II menjadi 3,7 yang termasuk kategori baik, aktivitas mengajar guru dengan menggunakan model pembelajaran kooperatif type picture and picture pada setiap siklus meningkat. Hal ini ditunjukan dengan skor rata-rata pada setiap siklus, pada siklus I skor rata-rata aktivitas mengajar guru adalah 2,8 yang termasuk kategori cukup dan meningkat pada siklus II menjadi 3,6 yang termasuk kategori baik, dan gambaran peningkatan hasil belajar siswa kelas XI IPS ${ }^{2}$ SMA Negeri 2 BauBau terlihat bahwa terjadi peningkatan presentase ketuntasan belajar dari siklus I ke siklus II. Pada siklus I presentase ketuntasan sebesar $67,5 \%$ atau 20 siswa telah mencapai KKM akan tetapi belum memenuhi ketuntasan secara klasikal yaitu minimal $80 \%$ dan pada siklus II presentase ketuntasan sebesar $87,5 \%$ atau 28 siswa telah mencapai KKM. Dengan demikian ketuntasan secara klasikal dari penelitian tindakan kelas ini telah terpenuhi yang berarti pula model pembelajaran kooperatif type picture and picture dapat memecahkan masalah belajar siswa kelas XI IPS ${ }^{2}$ SMA Negeri 2 BauBau.

\section{Saran}

Berdasarkan kesimpulan di atas, maka peneliti dapat menyampaikan beberapa saran berikut yaitu bagi sekolah khususnya SMA Negeri 2 BauBau dapat mencoba menggunakan model pembelajaran kooperatif type picture and picture dalam upaya meningkatkan hasil belajar siswa serta meningkatkan kualitas belajar siswa selama proses pembelajaran pada mata pelajaran geografi, bagi peneliti selanjutnya, teruslah belajar dan menggali informasi lebih jauh tentang model pembelajaran kooperatif type picture and picture untuk mempertajam kemampuan dalam menggunakan media ini pada kesempatan-kesempatan berkutnya agar memberikan hasil yang jauh lebih optimal, dan dalam penelitian ini, peneliti menyadari masih ada kekrangan-kekurangan baik dalam hal perencanaan penelitian sampai dengan penarikan kesimpulan. Karena peneliti juga hanyalah manusia biasa yang tidak sempurna dan tidak luput dari kesalahan.

\section{Ucapan Terima Kasih}

Terima kasih kepada pembimbing 1 Bapak Laode Amaluddin, S.Pd., M.Pd dan pembimbing 2 Bapak Laode Nursalam., S.Pd., M.Pd. kepada reviewer dan editor saya di pendidikan geografi. Kepada orang tua yang saya sayangi dan saya cintai, kepada sahabatsahabat saya, dan teman-teman saya yang telah memberikan motivasi dan bantuan.

\section{DAFTAR RUJUKAN}

Huda, Miftahul. (2013).Cooperative Learning Metode, Teknik, Struktur, dan Model Penerapan. Pustaka Pelajar: Yogyakart.

Efendi,M.Lukman. (2017). Penerapan model pembelajaran kooperatif untuk meningkatkan keterampilan sosial. Jurnal nasional Volume 1 No 2 Desember 2017. Lampung.

Aprilia, Evi, dkk. (2013). Pembelajaran kooperatif picture and picture untuk meningkatkan minat dan prestasi. 
Jurnal penelitian geofrafi Volume 1 No 4. Lampung.

Gaffer,Aden Arif. (2018). Penerapan model pembelajaran kooperatif tipe picture and picture untuk meningkatkan hasil belajar siswa. Jurnal nasional Volume 3 Nomor 1 April 2018. Majalengka.

Armayani, dkk. (2019). Peningkatan Hasil Belajar Geografi Siswa Melalui Penggunaan Model Pembelajaran Kooperatif tipe Teams Games Tournamen. Jurnal Penelitian Pendidikan Geografi Volume 4 Nomor 4 Oktober 2019.

Januarty, Restu, dkk. (2017). Model pembelajaran Kooperatif Picture and Picture dalam meningkatkan kosa kata siswa. Jurnal dan ilmu pendidikan Volume 4 No 1 Juni 2017.

Mizayanti,dkk. (2017). Model Pembelajaran Kooperatif Picture and Picture Untuk Meningkatkan Hasil Belajar Siswa pada Konsep Cacat Mata. Jurnal Nasional 30 Oktober 2017. Aceh

Ramli,dkk. (2016). Penerapan Model Pembelajaran Kooperatif Tipe Picture And Picture Untuk Meningkatkan Hasil Belajar Geogrfi Sub. Materi Dinamika Litosfer Kelas X-7 SMA Negeri 1 Lohia. Jurnal Penelitian Geografi, 1(1).

Fauziah, Tati. (2014). Penerapan Model Pembelajaran Kooperatif Tipe Picture And Picture Pada Materi Peninggalan Sejarah di Sekolah Dasar Negeri Banda Aceh. Jurnal Pesona Dasar Volume 2 No 3 Okober 2014. Aceh.

Suprijono,Agus. (2013). Cooperative Learning. Yogyakarta: Pustaka Belajar.

\section{Editor In Chief}

Rosmini Maru

rosminimaru@unm.ac.id

Publisher

Geography Education, Postgraduate

Program, Universitas Negeri Makassar

Jl. Bonto Langkasa Gunungsari Baru

Makassar, 90222 Kampus PPs UNM

Makassar Gedung AB ruang 01 , Indonesia

Email : ugj@unm.ac.id

Info Berlangganan Jurnal

085299874629 / Ihsan

Fenny Endrayani, La Ode Amaluddin, La Ode Nursalam, Rahma Musyawarah, Syukri Nyompa Peningkatan Hasil Belajar Geografi Siswa Menggunakan Model

Pembelajaran Kooperatif Tipe Picture And Picture 